Archived version from NCDOCKS Institutional Repository http://libres.uncg.edu/ir/asu/

\title{
Appalachïan
}

$\overline{\text { B O O N E, N O R T H C A R O L I N A }}$

\section{The Importance Of Personal And Contextual Factors In Resolving Conflict Between Sexual Identity And Christian Upbringing}

\author{
By: Denise L. Levy
}

\begin{abstract}
This study explores how gay, lesbian, and queer (GLQ) individuals who are raised in Christian families resolve conflict between their sexual identity and religious beliefs. Semistructured interviews were conducted with 15 GLQ participants who revealed a five-stage process by which they resolved conflict between sexual identity and religious beliefs. Analysis of interview transcripts delineated core categories of personal factors (reflective abilities, strength and resiliency, anger, creativity, and humor) and contextual factors (family, community, church) that affected each of the five stages. In addition to providing details about the core categories of personal and contextual factors, this article will also address implications for social workers serving GLQ clients with a Christian upbringing. Recommendations for future research include the development of evidence-based interventions designed to enhance these personal and contextual factors.
\end{abstract}

Denise L. Levy (2011). The Importance of Personal and Contextual Factors in Resolving Conflict Between Sexual Identity and Christian Upbringing, Journal of Social Service Research, 38:1, 56-73. Publisher version of record available at: http://dx.doi.org/10.1080/01488376.2011.586308 


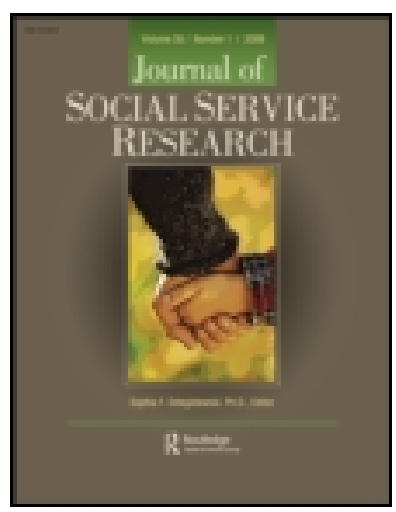

\section{Journal of Social Service Research}

Publication details, including instructions for authors and subscription information: http://www.tandfonline.com/loi/wssr20

\section{The Importance of Personal and Contextual Factors in Resolving Conflict Between Sexual Identity and Christian Upbringing}

Denise L. Levy ${ }^{a}$

${ }^{a}$ Appalachian State University, Department of Social Work, Boone, NC

Available online: 27 Jun 2011

To cite this article: Denise L. Levy (2011): The Importance of Personal and Contextual Factors in Resolving Conflict Between Sexual Identity and Christian Upbringing, Journal of Social Service Research, 38:1, 56-73

To link to this article: http://dx.doi.org/10.1080/01488376.2011.586308

PLEASE SCROLL DOWN FOR ARTICLE

Full terms and conditions of use: http://www.tandfonline.com/page/terms-and-conditions

This article may be used for research, teaching, and private study purposes. Any substantial or systematic reproduction, redistribution, reselling, loan, sub-licensing, systematic supply, or distribution in any form to anyone is expressly forbidden.

The publisher does not give any warranty express or implied or make any representation that the contents will be complete or accurate or up to date. The accuracy of any instructions, formulae, and drug doses should be independently verified with primary sources. The publisher shall not be liable for any loss, actions, claims, proceedings, demand, or costs or damages whatsoever or howsoever caused arising directly or indirectly in connection with or arising out of the use of this material. 


\title{
The Importance of Personal and Contextual Factors in Resolving Conflict Between Sexual Identity and Christian Upbringing
}

\author{
Denise L. Levy
}

\begin{abstract}
This study explores how gay, lesbian, and queer (GLQ) individuals who are raised in Christian families resolve conflict between their sexual identity and religious beliefs. Semistructured interviews were conducted with 15 GLQ participants who revealed a five-stage process by which they resolved conflict between sexual identity and religious beliefs. Analysis of interview transcripts delineated core categories of personal factors (reflective abilities, strength and resiliency, anger, creativity, and humor) and contextual factors (family, community, church) that affected each of the five stages. In addition to providing details about the core categories of personal and contextual factors, this article will also address implications for social workers serving GLQ clients with a Christian upbringing. Recommendations for future research include the development of evidence-based interventions designed to enhance these personal and contextual factors.
\end{abstract}

KEYWORDS. Person-in-environment perspective, sexual identity, Christianity, grounded theory

Religion is important to the lives of many people, and Christianity continues to be the dominant religion in America. Numerous people, though, struggle to make sense of their religious beliefs in the context of their everyday lives. Because some Christians and Christian churches consider homosexuality to be a sin, those identifying as gay, lesbian, or queer (GLQ) may experience conflict between sexual identity and religious beliefs. This conflict can be very intense and emotional, and may lead individuals to become critical of institutionalized religion or to seek more accepting congregations (Rodriguez \& Ouellette, 2000; Shallenberger, 1996; Yip, 2003).
Research indicates that gay and lesbian individuals with a Christian upbringing commonly experience identity conflicts (Couch, Mulcare, Pitts, Smith, \& Mitchell, 2008). The literature on this subject includes several studies focusing on the impact of gay-positive or welcoming churches (Lukenbill, 1998; McQueeney, 2003; Rodriguez \& Ouellette, 2000) as well as research examining the religious and spiritual lives of gay and lesbian individuals (Beckstead \& Morrow, 2004; Buchanan, Dzelme, Harris, \& Hecker, 2001; Donnelly, 2001; Lease, Horne, \& Noffsinger-Frazier, 2005; Mahaffy, 1996; Shallenberger, 1996; Thumma, 1991; White \& White, 2004; Yip, 1998, 2003). Most of these

Denise L. Levy, PhD, LCSW, is an Assistant Professor at Appalachian State University, Department of Social Work, Boone, NC.

Address correspondence to: Denise L. Levy, PhD, LCSW, Appalachian State University, Department of Social Work, ASU Box 32155, 9C Chapell Wilson Hall, Boone, NC 28608 (E-mail: levydl@appstate.edu). 
studies focus on the end result of the conflict between GLQ identity and a Christian upbringing and explain that individuals will reject their sexual identity, reject their Christian identity, integrate these two identities, compartmentalize, or live with the conflict (Buchanan et al., 2001; Rodriguez \& Ouellette, 2000; Yip, 2003). However, understanding the process of resolving conflict rather than just knowing the final result is vital for social workers and helping professionals whose clients are struggling with this conflict.

Only four of these studies emphasize or claim to describe the process of resolving conflict between sexual identity and religious upbringing (Mahaffy, 1996; McQueeney, 2003; Shallenberger, 1996; Thumma, 1991). Mahaffy (1996) surveyed 186 lesbian women to understand the effects of Christian identity on internal and external conflicts related to sexual orientation. For these women, evangelical identity led to more intense conflicts, especially internal conflicts. Although respondents acknowledged modifying religious beliefs and/or living with dissonance between religion and sexuality, they did not describe the process of conflict resolution in detail.

Focusing more on process, Shallenberger (1996) selected 26 gay and lesbian individuals out of 300 survey respondents to interview about their Christian faith. These in-depth interviews, which sometimes lasted up to 5 hours during two sessions, revealed a three-stage process of resolving conflict between sexuality and spirituality: questioning, reclaiming, and reintegration. Shallenberger's study, though, only included those who individuals maintained their Christian faith.

Rather than presenting in-depth information on the process by which participants resolved conflict between gay and evangelical identities, Thumma (1991) discussed steps taken by Good News, a gay, conservative Christian organization, to assist its members in accepting themselves. This organization teaches members that it is possible to be gay and Christian, presents doctrine to support this stance, and facilitates integration of gay and Christian identities by providing a social outlet. This study emphasized the importance of social networks and critical review of doctrine to integrate identity.

Similar to Thumma's (1991) research, McQueeney (2003) completed interviews with 21 gay and lesbian church members and 4 church pastors of 2 mainline, Protestant, welcoming congregations. McQueeney's grounded theory study identified the following strategies used by churches to assist their members in dealing with conflict between sexual orientation and Christian identity: defining sexual identity as secondary to Christian identity, normalizing gay or lesbian identity by reinforcing common values across sexual categories, and connecting the notion of fighting social injustice with being gay or lesbian.

Although these four studies provide some information about the process of conflict resolution and how welcoming churches may be helpful in this process, they only include participants who continue to identify as Christians and omit individuals who have left the faith. To truly understand the process of resolving conflict between GLQ identity and Christian upbringing, individuals who have converted should be included. In other words, leaving the Christian faith is how many individuals resolve this conflict, and their experiences should be highlighted alongside the experiences of those who integrate their GLQ identity and Christian faith. Furthermore, prior studies mainly took place in the United Kingdom and Northern U.S. cities such as New York and Chicago (Lukenbill, 1998; Shallenberger, 1996; Yip, 1998, 2003). However, Christianity and homophobia are both prevalent in the Bible Belt region of the United States, an area of the country where this research is limited.

The study discussed in this article addresses the gap in the literature in several ways. To begin with, it focuses on the process of conflict resolution rather than just the end result. Participants in this study identified that they had resolved conflict between sexual identity and religious beliefs and were asked to recount their process of resolution from beginning to end. Additionally, this study includes participants who identify today as Christian and non-Christian. It also highlights a population that has previously been excluded from this type of research-queer-identified individuals. To identify as queer refuses the bounds of binary definitions of sexuality and is inherently political. This group seems most appropriate for a study that questions the notion that one cannot be both GLQ and Christian. Finally, this 
study took place in the Bible Belt and sought to understand conflict experienced by GLQ individuals with a Christian upbringing in a location that is ideal for this type of research.

The purpose of this study was to understand the process by which GLQ-identified individuals with a Christian upbringing resolve the conflict between their sexual identity and religious beliefs. Although this article will only focus on the second research question, there were four research questions that guided this study. First, how do participants define the conflict between their sexual identity and religious beliefs? Second, what personal and contextual factors shaped their efforts to resolve this conflict? Third, what is the process by which individuals resolve this conflict? Finally, how do participants describe their resolution of this conflict? This article will begin with a very brief description of the overall results of the study, will continue with a focus on the personal and contextual factors that were important for participants as they resolved conflict between sexual identity and religious upbringing, and will end with implications for social workers and helping professionals.

\section{METHODOLOGY}

Although research to date has focused on the outcome of the conflict experienced by GLQ individuals with a Christian upbringing, this study, which reports select findings from a larger research project (Levy, 2008), delineates the process by which individuals resolve this conflict. Researchers should use qualitative methodology when they want to "explore a topic about which little is known ... pursuing a topic of sensitivity and emotional depth ... to capture the 'lived experience' from the perspectives of those who live it" (Padgett, 1998, pp. 7-8). This study employed grounded theory, a type of qualitative research, which focuses on generating theory grounded in the qualitative data (Creswell, 2007; Glaser, 2007). In addition to generating a substantive theory, the process included the simultaneous collection and analysis of data, generation of codes from the data, constant comparison of data, memo writing, and identification of core categories.
After this study was approved by an institutional review board, participants were recruited through flyers placed in welcoming churches and businesses catering to the GLQ population and through information posted on listservs related to faith and sexuality. Those interested in the study participated in a prescreening over the phone, which lasted no more than 10 minutes. The prescreening included a description of the study by the researcher, a series of questions for interested individuals to ensure they met the study's criteria, and time for individuals to ask any questions they had about the study. To participate in the study, individuals had to be at least 18 years old; live within a 3-hour drive from the central research location; selfidentify as GLQ; self-identify as having a Christian upbringing; self-identify as having experienced and addressed conflict between religious beliefs and sexual identity; be willing to participate in a face-to-face interview; and be willing to participate in a follow-up interview if necessary.

Fifteen participants, 7 females and 8 males, were selected using maximum variation and theoretical sampling. Generally, the sample was diverse based on age, gender, religious background, and current faith identification. Participants $(N=15)$ included 6 lesbians, 6 gay men, 2 identifying as gay and queer, and 1 identifying as queer. Education affiliation included 7 with Bachelor's degrees, 4 with Master's degrees, 1 with an Associate's degree, and 3 who had completed high school; ages ranged from 19 to 43 years, with a mean age of 29 years old. The participants in the sample indicated being raised in the following denominations: Free Will Baptist $(n=1)$, Jehovah's Witness $(n=1)$, United Methodist $(n=1)$, Lutheran $(n=1)$, various Christian $(n=1)$, Church of Christ $(n=2)$, Southern Baptist $(n=3)$, and Catholic $(n=5)$. Their current faith identifications are: Christian $(n=4)$, spiritual $(n=4)$, Catholic $(n=3)$, Episcopal $(n=1)$, Agnostic $(n=1)$, Atheist $(n=1)$, and Wiccan $(n=1)$.

During a 12-month time period, semistructured interviews were conducted, and they lasted from 50 to 105 minutes. These interviews were held at locations comfortable to the participants, including my university office, participants' offices, and participants' homes, all located in the Southeastern United States. Beginning 
with consent forms, these meetings incorporated interview questions related to the purpose of the study and each of the research questions (see Appendix). Interviews ended with a debriefing statement connecting participants to further resources in case they experienced emotional or psychological stress due to topics discussed during the interview. The recorded interviews were transcribed, and transcripts were coded using grounded theory methods of open, focused, and axial coding.

\section{FINDINGS}

The findings of this grounded theory study led to three conclusions. First, resolving the conflict between sexual identity and religious beliefs is a five-stage process of internal conflict resolution. These five stages are an awareness of the conflict, an initial response to the conflict (including secrecy, increased religious involvement, and depression), a catalyst of new knowledge propelling participants forward, steps of working through the conflict (including seeking information, reflection, discussion, and trying new behaviors), and resolution of the conflict (including personalized faith and acceptance of sexual identity). This first conclusion, which provides a five-stage process of conflict resolution, addresses Research Questions 1 (in the awareness of the conflict stage), 3 (in all five stages), and 4 (in the resolution of the conflict stage). The second conclusion, that personal and contextual factors affect every aspect of the resolution process, relates to the second research question, which is the focus of this article. Finally, the third conclusion is that faith development and sexual identity development are intertwined and fluid constructions.

Grounded theory "involves the identification of the core category or story around which the analysis focuses" (Ezzy, 2002, p. 92). In this study, the core categories were the personal and contextual factors that affected every aspect of the process of resolving conflict between sexual identity and religious beliefs. These core categories are outlined below.

\section{Personal Factors}

Analysis revealed five personal factors that helped participants manage or deal with the conflict between sexual identity and religious beliefs: reflective abilities, strength and resiliency, anger, creativity, and humor.

\section{Reflective Abilities}

Reflecting on and critically thinking through their situations helped participants move toward resolving the conflict between sexual identity and religious beliefs. For Mark, reflection in and of itself was a spiritual act. He noted, "I'm a very independent person. I have a lot of intellectual independence. And I feel that it's important to God to express myself." Logan described reflection in much the same way and explained how helpful it was and is for him:

It's looking inward at myself. It's believing that I'm smart enough to have my own ideas. I'm smart enough to figure this out on my own. There's enough spirit in me, and that spirit in me is worth enough that I can investigate that. I' $m$ not alone here. I can educate myself. Once again, I like to read. I like to read-not just [authors] who agree with me, but people who don't. I want them to challenge me. I have to look at my own concepts and ideas and come to terms with those and reflect on those and meditate on those. And, certainly, no one else can tell me what's right or wrong. They can, but I don't have to believe them. I have to figure that out for myself.

Another participant, Allen, whose father is a minister, found that it was important for him to figure things out for himself rather than rely on his father. He explained:

Something that's helped me along that path is the observation of the world versus seeing what my father's observation of the world is, and seeing that they're different, seeing the massive difference between the two. I'm slowly able to form my own 
opinion and allow it to be different than my father's and allow it to be okay.

As she stepped outside of her "Christian bubble," Allison also formed her own views: "Opening my mind up to what truths are out there for me has been really good and really helpful to discover myself and my identity and how I really feel about the different parts of my life."

Participants discussed the importance of analyzing various positions on issues related to Christianity and homosexuality. Melanie's personal reflection, for example, had to do with learning about and critically thinking through several different stances. She explained in a matter-of-fact way:

When an argument is presented in front of me, I have this need to see more than one side. I think that that definitely helped a lot, in terms of how things were presented to me in my church. I wanted to understand not only why there were all these positions against who I was, but to also understand positions. I love to learn, so I think that helps with my desire to have more resources on it and understand it.

Reflection stood out among the personal factors as one of the most important elements in assisting participants in working through this conflict.

\section{Strength and Resiliency}

In addition to reflection, participants noted that their own strength and resiliency helped them cope with the conflict between sexual identity and religious beliefs. In the fact of bullying, humiliation, and guilt, individuals explained that they had to draw strength from within to survive. Trey said, "I' $m$ a person that can take a lot, and I think I'm pretty strong that way." Chad also had "a great deal of will and determination to have gotten through that and to come out of that." Toward the end of his interview, William made a related remark:

It wasn't as easy as it sounded. But the journey was worth it. I wouldn't change any- thing, honestly. Even the harassment and the bullying and all that crap that I got and dealt with in high school, I wouldn't change any of that either because it all came together. I do think things happen for a reason and that it all has come together in a certain way to make me who I am.

Like William, Jake was thankful that his journey made him stronger. He explained: "I'm stronger because I had to force myself to think differently, and I'm glad I had to force myself to step outside of myself at a younger age and [tell myself], 'I am okay.' I think that's made me stronger." Logan was also forced to rely on his strength at a young age, as noted in the following remarkable account of his resiliency:

I'm an incredibly strong person. I grew up with my grandmother who raised me. She was an incredibly strong woman. Didn't always make the best decisions, as we all don't, but she was incredibly strong. Her husband died when her children were 13 and 15 , and she had to raise them. She had gone right from her daddy's arms to her husband's arms. ... I grew up very strong. Both my parents were and are functioning alcoholics and sometimes barely functioning alcoholics. I grew up very, very young, at 7 [or] 8, having to stay up late to turn the stove and oven off to make sure the house wouldn't burn down. I think that built just a very strong character. I told you I grew up being 40 already. I really did. ... And I think that equipped me really well to deal with those things. Ever since I could remember, I'd always been called sissy and fag. I didn't know what those things meant. I was used to being teased and all that. Having gone through that, again, I was just resilient. It didn't mean that it didn't hurt. I cried a lot. I got upset a lot. But I quickly bounced back. ... And it made me really strong because-am I going to be strong here or I am just going to curl up in a ball and cry? Well, maybe I think too highly of myself, but I'm not letting anybody do that to me. If you look at lots of stories and so forth of young people growing up 
homosexual, they tend to take one or the other path-very fragile or very strong willed. You have a choice to make. You're going to let that get to you or you are going to not let anything get to you, or at least not let it show to anybody. So I think that what helped was having to grow up so young so fast because of other things beyond the homosexuality. I got my driver's license, and I moved in with my grandmother full time because she was dying of cancer. My mother wouldn't do it, and the other daughter, my aunt, wouldn't do it. So I moved in with her and went to school. I went to high school full time and worked a part-time job and cooked all her meals at night so they were ready for her the next day and took her to all her chemo and radiation. You just have to grow up. You have to deal with all that. And so I think that there were those outside influences that kind me forced me to grow up in those respects and just lent themselves very well to the struggles that I would have to go through.

Similarly, Allen gave poignant advice on where to find strength and resiliency: "If the whole world's against you - or it feels like the whole world is against you, don't be afraid because you still have yourself."

\section{Anger}

For several participants, feeling and expressing anger was an important part of their experience. This anger was, first and foremost, directed at the church or religious establishment. William remarked, "I went through that whole angry idea of, 'Well, if that's your God, then I'll have nothing to do with Him.' . . . I had to do that in order to be able to come out." Laura drew the same conclusion:

I was so angry at the church because my idea was that the church was supposed to be this place that loves you and accepts you and helps you grow and is this force of change in the world and is this light shining in the darkness, but it caused more misery than it cured.
Sarah, who went to a Catholic school, was angry with religious leaders and religion in general:

And when I got to college and I was able to step back, I was living in a whole different state. Everything was different, a whole different geographical state, not mental state. [laughs] It gave me the permission to be angry and I was so angry about all of it. I was like, "Religion killed my friend, religion got my other friend kicked out of school. Religion got my third friend who's also very close living in a garage." Who wouldn't be angry? ... A great way for me to vent anger was every Sunday I didn't go to church. I felt like it was actually being active and angry. I didn't think of it as just sleeping in. I was waking up knowing I wasn't at church at that moment and that was an actual proactive expression of hate towards all the stuff that happened. ... I was still really angry about the whole thing, on a macro level, on a systemic level.

Although Chad feels bad about this now, he used to "walk around [his college] campus and say, 'I can smell a Christian from a mile away.' " He explained that he was "pretty confrontational about it [and] pretty bitter about it all."

In addition to anger at organized religion, some individuals became frustrated with God and with themselves. For example, Allen commented:

When I was younger, it was anger at myself for being different. Then it would become anger at other people because I was different. I was having to be angry at them because I didn't know how to justify it [same-sex attraction] in myself. As I got a little older, in high school and in college, and I saw that my father didn't speak for God, it was anger at my father, which then became anger at God.

Jennifer expressed a similar sentiment: "I definitely felt angry because I didn't understand why this was happening to me. ... I think I was angry with the situation in general. I was angry 
at God." After being angry for years, Jake said: "You just get pissed off. You're just tired of it. As each year goes by, you're tired of feeling so guilty, and one day you just explode. One day you just say, 'Screw it.",

\section{Creativity}

Several participants talked at length about personal creativity and about how artistic outlets provided a means for expressing emotions such as anger in a safe space. As an artist, Jake explained that he "had an outlet to express myself though, art. That was very nice and that was very therapeutic, because I had this outlet to express my emotions, which seemed so bottled up." Like Jake, Sarah found a forum where she could openly express her emotions:

I was going to be a creative writing major, so a huge amount of my creative writing stuff, which now looks like journaling, but at the time I thought it was fabulous prose... And that helped me to think about what I was angry about and really form it into full thoughts instead of just this storm.... So that was very useful to me in processing [my anger]. Also I took part in poetry readings and things. So, of course, when you're 19 and taking your secondever creative writing semester, and you perform at a poetry reading, everybody's standing up and just has horrible poems that they're reading out loud, but they really feel strongly about. So I got to just lay it all out and say this stuff in a socially acceptable way. ... And I did theatrical poetry. So sometimes I would be standing on top of a table or screaming or rolling on my back, but I really got to communicate this upsetness [sic] in a socially acceptable and supportive atmosphere to people that I'd never met before. And that was really purging and useful as well.

In addition to Jake and Sarah, Chad found an outlet in theater and the performing arts. In fact, he is currently working on an important project that works to give a voice to "the people that are spiritual and liberal."

\section{Humor}

In addition to creativity, humor was vital to a couple of individuals in dealing with the conflict between sexual identity and religious beliefs. Jennifer described her sense of humor:

I like to make people laugh, so I guess that helped me deal with things because I always shrugged it off. Like, "Oh, I'm still the same person" and try to make a joke about something. That made the transition [to identifying as a lesbian] a little easier.

Chad has always believed that "sometimes the best lessons that I'm learning are the ones that just make me smile." He went on to say that he "was the most miserable when I was not able to call on my sense of humor." Unlike Jennifer and Chad, Sarah was a little unsure about her sense of humor. She explained, "I want to say a sense of humor helped me. ... I think I try to act like [it did]." Sarah did, however, find some humor in the somewhat "ridiculous" fact that she had to come out to her parents twice because they forgot about it the after the first time she told them:

I told [my dad] the whole funny story [about how I had come out once before]. He's like, "I don't remember that at all, but that really does sound like something that would have happened in our house at that point, so you're probably right." It's like, "I remember it pretty clearly." . . So I just think it's very funny. And Dad's probably forgotten again, and they'll re-figure it out sometime down the road or they won't.

Related to finding humor in difficult situations, Laura discussed her generally optimistic outlook on life:

I'm also generally optimistic. There are people who tend towards depression. I tend towards anxiety, but I don't tend towards despair. So, you can't keep a spirit down that wants to get up again. So, when faced with the choices, "Okay, I can believe that I'm bad and awful and evil and wrong" 
or "I can find a new way to interpret all this and do some research," I'm definitely going to take door No. 2.

\section{Contextual Factors}

In addition to personal factors, participants were influenced by their environments or contexts in which they experienced the conflict between sexual identity and religious beliefs. In this section, I describe the importance of three contextual factors for participants: family, community, and church.

\section{Family}

One distinction participants made regarding their family members was whether or not they had come out to them. For instance, Allen explained: "I never felt like my parents would really love me if they knew who I was." He went on to say that his decision to stay in the closet was based on this difficult experience:

I had some conversations with my mother when I was in college and she said something about a coworker whose son who just came out and she was saying, "If one of my sons came out I would still love them, but I couldn't have anything to do with them." That helped form part of my decision of whether to tell my parents or not.

Similarly, Trey said, "My dad doesn't know," because "he's pretty antihomosexuality and not really at all condoning of it."

Unlike Allen and Trey, most participants have come out to their family members, some of whom expressed disapproval. Laura learned early on how her family felt about homosexuality: "My favorite joke in middle school that I heard directly from my parents was 'God made Adam and Eve, not Adam and Steve,' which was really funny until I was about 14 and realized that, 'Ew, I kind of like my best friend.'” Mark teared up when he described deep rejection by his family after coming out to them:

I knew I was going to lose it all. I knew that they were devoted enough to the religion that if they had to choose, they would not choose me. And I was right. So, I started looking for a job. By that time, I was 18 and I had graduated from high school, so at least I could be on my own. ... I really shouldn't say that my mother kicked me out. I say ... I was invited to leave. Because the truth is, it was just really apparent that I had no place there. And so one day when everybody was gone, I took the clothes that I had and I put them in my car and I didn't come back. [crying] Sorry. ... It was a huge step. And it was a liberating step for me, but it nailed the coffin in my relationship with my family. And, we both, we all acknowledged that there was no turning back from that point. ... [My mom's] faith doesn't allow her to talk with me either, so every once in a while, we have these bizarre conversations that never skim below the surface. And she doesn't want to know anything about who I am or what I'm doing because she doesn't believe that I can be happy. So even though I'm much happier now than between 17 and $18 \ldots$ she continues to believe that I'm fooling myself. And my sister won't talk with me either.

Hannah's family also reacted negatively when she finally came out: "It was a big deal for them what other people thought about them and the family name. I was ruining the family name and [being] a bad example for my sisters." Deborah described her heartbreaking experience: "When I came out to my grandmother, the first thing she said to me was that I would be abolished to hell."

Several participants explained that their parents sought religious help for them after they came out. Mark's mom brought him church materials to read. Luke said that when his mom asked him about "talking to a priest about this or going to confession or seeking some kind of religious guidance about it," he was "really kind of taken aback because I didn't feel that there was anything wrong with me." Jennifer's parents also made her "go talk to my priest." Hannah's parents took her to a religiously based conference where she learned how to avoid "homosexual tendencies." 
On the other hand, some individuals found that at least some of their family members were accepting, or at least tolerant. William's parents surprised him by leaving their church after their pastor "told them that the only way that they were going to achieve my salvation was to kick me out of the family until I came to my senses." Like William, Melanie experienced acceptance from her family. Melanie's mom made her views clear early on:

My mom started talking to me about, not necessarily the church and homosexuality, but homosexuality in general when I was about 7 because I have an uncle who's gay. I asked her why he had so many high heels in his closet, which was funny. So, she started telling me there was absolutely nothing wrong with it. My grandmother always told me that there is nothing wrong with it.

As a final note on family, several of the participants explained that their GLQ communities became their families. Mark talked emotionally about the difficult loss of his immediate family:

I guess the main thing is about the word "family" and the meaning of it. Because even as a 29 -year-old gay man who has been ostracized from his family for over a year, the word "family" is very important to me, and the concept of family is very important to me. But it means something a lot different now because the people who were my biological family chose not to honor the concept.

Deborah also explained how the gay community is like her adopted family: "We have huge kinship of selected family, so to speak, and this is what we really rely on."

\section{Community}

Community climate and community resources definitely affect people who are GLQ. Sarah thought her story "would be really different" if she had grown up in the Southeast instead of the Northeast, where people "expect diversity, whether they want it or not." Although Jake did grow up in the Southeast, he lived in a progressive and large city. When he was 16, a local bookstore brought in an academic author who had written a book on homosexuality and the Bible. Jake said that seeing this man speak "did a lot" for him. It helped him to "be okay" with himself and know that he was "not a freak," and that "there are other people out there" who are also gay. As opposed to Sarah and Jake's experiences, Allison's community led her to believe that being gay is an option. She put it this way:

The people that I had been around my whole life are very conservative, politically and socially, very narrow minded about what's acceptable in terms of race and class. ... I never ever got the idea from anyone in my family or any of my friends that being gay was an option, or that it in any way was a good thing. There was no positive light ever shone on that at all.

Similarly, Hannah ignored her same-sex desires initially because she "knew it wasn't something that would be accepted" in her social circles.

Many of the participants, like William, lived in more than one town due to a family or individual move. William's family moved when he was in 10th grade to "the sticks." He talked about his difficult move from an urban area to the country:

I mean, our high school had like 500 people in it. And I went from this huge urban school to this tiny little redneck school in the middle of nowhere. And I immediately was labeled the school fag. And this was the first time I started hearing the words and the verbal [harassment]. And I did nothing to earn it. I think honestly it was more because I was a city boy in the middle of all these redneck country boys.

He went on to say that it was "only by comparison" that he realized that "it was probably a little more tolerant where I lived" before. Melanie also switched high schools. Her last school "was a bit more open, and that's why I came out when I was in that high school." 
Allen and Hannah both experienced their first same-sex experiences once they moved to Christian colleges. With this experience, Allen felt "a lot of turmoil." He know that he was "supposed to be here strengthening my faith, finding my faith, becoming a minister or whatever I was going to do with my life, but that homosexuality followed me to school." Hannah also opted to attend Christian college so that she could focus on her faith. Instead, a light bulb went off when she "met people who were involved with the church who did accept people who were gay."

Several participants discussed support networks that they found or formed while they were in college. For example, Laura sought out likeminded people at her university and "formed an underground support group." Even though the school would not give them "club status," they "put up flyers" to advertise meetings. Laura's group included people "from different faith traditions," and it provided "peer support." Deborah also discussed the importance of the gay and lesbian community at her college:

I was very thankful to be in an environment where I had people that had gone through it before, others that haven't yet, but there were people that were there for me. Most of them were my age. We did have a couple of professors and they did the whole "safe space" thing, where they weren't gay, or might be, but they were there if you needed support. And then [Parents, Families, and Friends of Lesbians and Gays (PFLAG)] actually held their meetings on our campus, which was really nice.

Jennifer "grew up in a fairly small town," and when she went to college, she "learned about a lot of issues in the world that I really hadn't been exposed to. That's what started really causing me to challenge my faith and challenge what I believed in as a person." When Luke was in school, his roommate was gay and came out to him. For Luke, meeting other gay men in college was a "very big influence" for him because he realized that being gay "was just another part of identity." Laura's college community was also very positive, so much so that she "never came back." She "resolved the dissonance by staying away" from her hometown.

For others it was not college but a move to a new city was symbolic of starting their new lives as GLQ individuals. Allen described his thoughts during his drive to the large city where he moved after college:

After college, when I moved to [the city], I was like, "I'm tired of lying. I've got this comfortable distance between me and my family. Nobody knows me in [the city]. I can be anything that I want to be. Let's just be me."

Allen's move affected his outlook on life. He was able to "see the massive difference between" his "observation of the world" and his "father's observation of the world." Sarah's move was also a way for her to start over. She realized that sinking herself "into religion to try and find the answer" to the conflict between sexual identity and religious beliefs "wasn't working." So, she "decided to try being agnostic for a while and not go to church." Sarah explained, "I was living in a whole different state. Everything was different, a whole different geographical state."

As a final note on communities, several individuals reported that they missed the religious and spiritual communities of their childhoods. For example, Laura was writing in her journal one day when she realized that she "missed having the spiritual community." Trey longs for a religious community as well and said that he wants "to try to find a gay Catholic group." Like Laura and Trey, Jake stated: "I miss a community of people there [so] if something happens you can call on these people."

\section{Church Doctrine}

Finally, church doctrine proved to be an important context for participants. Christian doctrine regarding homosexuality can fall along a spectrum from accepting and welcoming to disapproving and condemning. Because participants in this study identified that they experienced a conflict between sexual identity and religious upbringing, most grew up in churches that were not totally accepting of homosexuality. 
In Mark's church, for example, members "believe that if you are a Jehovah's Witness and you choose to leave the organization, the only way to bring you back is to shun you." Mark knew that if his family and friends followed this tenet, they would not "have a dialogue with anybody who leaves the church." Thus, coming out meant losing his family and friends permanently. Luke's church is not totally accepting either. Although he is out to his family, friends, and colleagues, Luke said that he "probably would not come out to anyone from the church community. Yeah, something I struggle with is to go to church and ... know that I still have to kind of hide this part of me." Trey acknowledged that church doctrine affected his sexual identity and sexual activity. Even after he "came to terms" with his homosexuality, he was "still attending church and hearing what they say on the Catholic network and what priests say." Trey got the message that he should not "practice" or act on his same-sex desires. He explained further:

I thought I was always going to go with the Catholic faith, and say that I'm gay, but just not practice. Then I did practice, and I had sex, and I'd always feel guilty afterwards. I kind of still always do. I know that what I was doing just wasn't really fulfilling because I would really like a relationship. But basically it's really wrong for anybody, according to the Catholic religion, even a straight person unless it's in marriage. That kind of makes it a little bit easier, I guess. My mom [has] been through three divorces, and so, for a lot of people, it's hard to go down the right road with the Catholic Church.

In other words, Trey's religious upbringing influenced him to try to live a celibate life when he first came out.

Jennifer and Logan were actually supported by their churches. When Jennifer's parents sent her to a priest, "he was a little more liberal, working for peace and justice. ... He was really supportive." The priest told Jennifer that if she identified as a lesbian, there would be "some ramifications within the church. ... But he really just encouraged me to think it through and [offered] himself as a sounding board if I needed to talk further about it." Logan emphasized that his local church helped him as he came out:

I've always said and I will continue to say that my church, my religious beliefs, those that I surrounded myself with and were religious and a part of my Christian background were the ones who allowed me to be homosexual and allowed me to be queer or gay. They certainly opened that door for me. Because I grew up in such a loving congregation, it never crossed my mind that God didn't love me or my church didn't love me.

\section{DISCUSSION AND IMPLICATIONS FOR PRACTICE}

It is not surprising that personal and contextual factors were important for participants as they sought to resolve conflict between sexual identity and religious upbringing. The literature reveals that individuals are often affected by their own abilities as well as the environments in which they live (Chuang, Liao, \& Tai, 2005; Vermunt, 2005). The remainder of the article will connect the personal and contextual factors to existing literature and then discuss implications for social workers and helping professionals who work with GLQ individuals with a Christian upbringing.

\section{Personal Factors}

The first personal factor, reflective abilities, is often emphasized in theories of development, such as Mezirow's (1997) transformational learning theory and Fowler's (1981) stages of faith. In Fowler's second stage of mythical-literal faith, for example, faith "is more logically and reality oriented than the faith of Stage One, due to the increasing $\operatorname{cog}$ nitive abilities of the child" (Green \& Hoffman, 1989, pp. 246-247). Further, the fourth stage of individuative-reflective faith has a "heavy emphasis upon the development of a rational and self-conscious "world view'" (Green \& Hoffman,1989, p. 247). In other words, Fowler's 
theory tells us that reflection is a key aspect in the development of faith. In this study, reflective abilities helped participants sift through all of the available information about Christianity and sexuality. For instance, Allison described a period in her life when she was "overanalyzing everything" and was "very skeptical." This critical analysis and reflection were important to participants throughout the entire process of conflict resolution.

The second personal factor expressed by participants was their strength and resiliency. Although these are actually two separate concepts, strength and resiliency are intertwined and were not distinguished by participants in this study. According to Laursen (2003), "Strengths are personal qualities, traits, and virtues ... that often are forged by trauma and loss" (p. 12). The second concept, resiliency, was defined by E. D. Miller (2003):

Resilient behavior is more than whether an individual has pathological symptoms or disorders of some sort after experiencing a major negative life event. But individuals who do not show such symptoms or disorders-despite the fact that clinically and statistically we would expect them to (due to the nature of a given stressor) - illustrate resilient behavior. Whether a particular therapist is working with individuals who have experienced a particularly severe life trauma or not, the therapist must help to show his or her clients how they have been able to achieve successes and triumphs in their lives (especially under adverse conditions). Psychologists and laypersons alike would be well advised to heed the words of the famous German philosopher Friedrich Nietzsche: "That which does not destroy me only makes me stronger." (p. 245)

E. D. Miller went on to say that although the concept of resiliency is often associated with children, it is also common in adults. In fact, Bonanno (2005) found that resilience, rather than trauma symptoms, "is typically the most common response following exposure to a potentially traumatic event" (p. 136). This study was no different; participants relied on strength and resiliency to cope with the conflict between sexual identity and religious beliefs.

Anger was another personal factor that aided participants as they coped with this conflict, and they expressed anger at their churches, organized religion, God, and themselves. This anger is consistent with Yip's (1998) findings in his study of gay Christians' perceptions of the Christian community; individuals in Yip's (1998) study were also overwhelmingly angry and disappointed with their churches. Further, in Yip's (2003) study of the religious beliefs of nonheterosexual Christians, he found that respondents were critical of the institutional Christian church and organized religion. In addition to anger at churches, participants in this study focused their emotions on their personal situations. This is similar to what Cass (1984) described in her theory of sexual identity development; people deal with homophobia and heterosexism through anger. Also described in the conflict resolution literature, anger can be viewed as a path to personal growth (Deutsch, Coleman, \& Marcus, 2006). By staying in tune with and expressing one's emotions in a healthy way, an individual can use anger as motivation to make positive personal changes and to advocate for social justice in society at large. In other words, anger serves the purpose of empowering, energizing, and mobilizing individuals.

A fourth personal factor that participants relied on was their creative abilities. The idea that creative responses arise out of conflict is also widespread in the conflict resolution literature (Deutsch et al., 2006). Further, helping professionals have long recognized the importance of creative outlets in handling stress. Leavitt (2002) maintained that "creative expression also relieves stress ... [and] can reduce pain and bolster the immune system" (p. 53). Art therapy is a kind of creative outlet, and according to Stephenson (2006), it fosters "exploration and emotional growth through creative expression" (p. 24). Art, along with theater and writing, provided an outlet for participants to creatively express their emotions. Laura, for example, has "always been a writer." She illustrated the importance of her writing: "I journaled and journaled 
and journaled. I journaled my way through high school and part of college."

Although the last personal factor, humor, was a surprise to me, the concept is not new in medical, psychological, and nursing literature. Indeed, laughter is associated with health benefits, such as an increase in endorphins and a decrease in stress-related hormones (Facente, 2006; Winter, 2006). There is even a group, the Association for Applied and Therapeutic Humor, which is committed to understanding the relationship between humor and health (Wojciechowski, 2007). There is considerable evidence in the literature that humor helps individuals cope with medical problems, stress, grief, sadness, oppression, and identity conflicts. According to Moran and Hughes (2006), "the beneficial effects of humour [sic] occur even in circumstances that are extreme or seem hopeless. ... The effect of this laughter seems to be selfaffirming and often provides a form of control in uncontrollable situations" (p. 504). Jennifer's sense of humor helped her manage this type of situation. She explained: "I like to make people laugh, so I guess that helped me deal with things because I always shrugged it off."

\section{Contextual Factors}

Analysis revealed that as with personal factors, the contextual factors of family, community resources, and church doctrine affected the entire process of conflict resolution. These factors are similar to what Benson (2004), in his discussion of adolescent spiritual and religious development, identified as important contexts: family, schools, peers, community, and congregations. Family is the first contextual factor to consider for GLQ individuals with a Christian upbringing. When individuals grow up in religious or even homophobic households, coming out can bring up problems for family members as well as for the individuals themselves (Lease \& Shulman, 2003; Saltzburg, 2004). Participants in this study experienced varied reactions from family members, and they ranged from acceptance to condemnation. Mark, who grew up practicing the Jehovah's Witness faith, has had little contact with his mother and sister since coming out. Sarah's parents, on the other hand, were fairly accepting of her sexual identity. Some participants, like Allen and Trey, have not come out to their entire immediate families for fear of rejection or disapproval. According to R. J. Miller and Boon's (2000) research with gay men, disclosing sexual identity to mothers is linked to the existing level of trust in the relationship. In other words, if a certain level of relational trust does not exist, it is less likely that a gay male will come out to his mother. Because parental support and approval can be so important during identity development, those who have not yet come out or those who experienced rejection after disclosing their sexual orientation have more difficulty resolving the conflict between sexual identity and religious beliefs.

The second contextual factor in this study was community resources. Participants discussed the various communities they lived in, and explained that they were able to manage and cope with the conflict better when they were surrounded by supportive communities. Shallenberger (1996) explained the importance of community for the gay and lesbian participants in his study:

As they progressed through their coming out, it appears to have been crucial that these gay men and lesbians find community, with one or more others who share some aspects of their spiritual journey. That goal has led many to look for a group of like-minded individuals. (p. 208)

Some of the participants in Shallenberger's study, as in this study, found community connections through "12-step programs or groups studying Wicca" (p. 208). In addition to Shallenberger, D'Augelli (2006) examined community resources for GLQ individuals, and he also created a community support network in a rural university town. When resources do not already exist, some may be forced, as D' Augelli was, to undergo "a reflective analysis of one's vulnerabilities" (p. 210) to overcome "personal barriers to involvement with change" (p. 210). Laura, a participant in this study, experienced a similar situation when she helped form an underground support group. She intensely described her emotional reaction to the situation: "They wouldn't 
give us club status. We were terrified. We'd put up flyers and they'd get ripped down."

The third contextual factor, church doctrine, also played an important role for participants in this study, and they described several different Christian views on homosexuality ranging from accepting to condemning. Because the individuals who were a part of this study all experienced conflict between sexual identity and religious beliefs, their childhood churches mostly fell on the condemning side of the spectrum. During the time that participants were resolving this conflict, most attended or at least visited more accepting Christian churches, such as Metropolitan Community Church (MCC), Unitarian Universalist churches, and Episcopal churches. These congregations were helpful to them in their efforts to manage this conflict. Chad, who still attends MCC, "knew after visiting the first Sunday that that was the place for me, and of course I joined as a member within weeks." Mark, who now attends an Episcopal church, also visited MCC and said that:

If it hadn't been for MCC, I would not have been able to come out. And I don't actually usually attend MCC churches anymore. I mean I very strongly self-identify as Episcopalian now. But I'm always going to be grateful to $\mathrm{MCC}$ for the ministries that they do provide because I wouldn't have been able to understand myself if it hadn't been for them.

The experiences of participants like Mark and Chad are supported by the literature. For example, Lease et al. (2005) found that individuals who "experience affirmation from their faith groups have increased psychological health through greater spirituality and decreased homonegativity" (p. 385). Several other studies have found that accepting churches, like MCC, have assisted GLQ individuals in their process of integrating their spiritual and sexual identities (Lukenbill, 1998; McQueeney, 2003; Rodriguez \& Ouellette, 2000). It is important to note, though, that not all of the participants in this study were satisfied with MCC. Several mentioned, as did Laura, that "it's a church about being gay." She elaborated:
I just want to be able to go to place where it doesn't matter. I don't want to go to church and be like, "Hey, you're gay and we're gay. God loves gay. We're gay. Yay. Praise Jesus." I don't want that. I just want a place where it's just not an issue. But I come back to the whole idea that if it's separate, it's inherently unequal.

In Thumma's (1991) study of gay Evangelicals, participants expressed similar feelings. For instance, one individual said, "I left the Metropolitan Community Church because I felt that they were putting gay before God" (p. 338). Another person from Thumma's study made a comment reiterating the inequality inherent in separate, progay congregations:

I consciously chose to be a member of a predominantly nongay congregation because I believe in the concept of the family of faith, the community of faith. Christians who are gay cannot afford the luxury of isolation. We have to be willing to risk the pain, the alienation, the separation, if we are to achieve any semblance of dialogue. (p. 342)

\section{Implications for Practice}

So what does all of this mean for social work practitioners? First and foremost, understanding the process by which individuals resolve conflict between sexual identity and religious upbringing can assist social workers as they work with GLQ clients. We can normalize the experiences of clients, provide a safe space for them, and simply listen.

Regarding the personal and contextual factors, social workers tend to view situations in a holistic way and have long recognized the importance of the person-in-environment perspective. In fact, the ecological systems theory, a foundational theory in the social work profession, combines the ecological perspective and general systems theory (Rothery, 2001). Rothery explained how this theory emerged:

Social work has wrestled with the need for ways of thinking about clients' 
situations that included a respect for individuals' and families' capacities for effective coping, but also recognized the critical importance of environment-the physical and social contexts that support, constrain, and shape our efforts to live gratifying lives. (pp. 68-69)

\section{Personal Factors}

Regarding the personal factors of reflection, strength and resiliency, anger, creativity, and humor, social workers can encourage clients to rely on and develop the attributes that assist them in making sense of their sexual identity and religious beliefs. Using a strengths-based approach, we can focus on clients' assets and help them apply these abilities to difficult situations. In a supportive and safe environment, our clients can talk through and reflect on their situations, while expressing emotions such as anger and humor. We can encourage them to utilize creative outlets such as art, poetry, and theater to cope with their experiences.

\section{Contextual Factors}

Regarding the contextual factors of family, community, and church doctrine, social workers can make a difference in several ways. First, therapists may be called upon to assist families when a family member has come out. Assisting family members in building communication and strengthening relationships is important. Additionally, for those clients who no longer have relationships with one or more family members, social workers can empower them to build their social networks and grieve the loss of family relationships.

In addition to working with families, social workers can work to provide safe spaces in their communities for GLQ individuals. We can raise awareness of issues faced by this population and can educate our communities and agencies on how to provide support. One way to accomplish this is by partnering with local organizations committed to this cause, such as PFLAG. Finally, we can advocate for laws and policies that will protect and provide equal rights to this population, especially for those laws and poli- cies related to employment, military service, education, bullying, health, marriage, adoption and parental rights, and hate crimes.

Finally, in relation to churches, we can partner with welcoming and accepting churches to educate the Christian community about this issue. With the media recently reporting on multiple suicides committed by GLQ young adults recently, it is especially important to dialogue with those who express varying church doctrine related to sexual orientation. Even though such conversations are difficult, we can work to ensure that GLQ individuals who do come out to their church communities find that their leaders and friends are willing to listen and communicate with them rather than shut them out.

\section{CONCLUSION}

In summary, the purpose of this study was to understand the process by which GLQ-identified individuals with a Christian upbringing resolve the conflict between their sexual identity and religious beliefs. This article reports the results of the following research question: What personal and contextual factors shaped participants' efforts to resolve conflict between sexual identity and religious beliefs? Grounded theory coding and analysis revealed five personal factors that helped participants manage or deal with the conflict between sexual identity and religious beliefs: reflective abilities, strength and resiliency, anger, creativity, and humor. In addition to personal factors, participants were influenced by their environments or contexts in which they experienced the conflict between sexual identity and religious beliefs. Analysis revealed three contextual factors for participants: family, community, and church.

The limitations of the study included a small sample size $(N=15)$ and nonrandom sampling. Because of these factors, the study findings are limited in generalizability. Additionally, there was a lack of racial diversity in the study sample. Although I used maximum-variation sampling, it became clear after the first five participants that all of the individuals contacting me about the study were White. I attempted to recruit people of color to participate in the study, but in the 
end, only three of the participants in this study were not White. Although these demographics are similar to the area in which the study took place, future studies should attend to recruiting diverse individuals from the beginning.

In addition to the limitations, this study had several strengths. Qualitative researchers ensure trustworthiness, also known as reliability and validity, in several ways (Merriam, 2009). This study used the following strategies: triangulation, peer examinations, member checks, rich description, a subjectivity statement, memo writing, and maximum-variation sampling (Bogdan \& Biklen, 2007; Maxwell, 2005; Merriam, 2009). Most importantly, this study highlights the voices of those who are often marginalized, GLQ individuals with a Christian upbringing. A final strength is that the study included a diverse sample based on age, gender, sexual orientation, denominational background, and current faith identification.

Additional research on the conflict between sexual identity and religious beliefs is needed, and future studies should attend to the limitations of this study, especially the racial diversity of the participants. In the future, research on this topic should extend to bisexual and transgender populations, encompass Muslim and Jewish individuals, include quantitative studies resulting in generalizable data, and contribute to the development of evidence-based interventions designed to enhance personal and contextual factors.

\section{REFERENCES}

Beckstead, A. L., \& Morrow, S. L. (2004). Mormon clients' experiences of conversion therapy: The need for a new treatment approach. The Counseling Psychologist, 32(5), 651-690. doi:10.1177/0011000004267555

Benson, P. L. (2004). Emerging themes in research on adolescent spiritual and religious development. Applied Developmental Science, 8(1), 47-50.

Bogdan, R. C., \& Biklen, S. K. (2007). Qualitative research for education: An introduction to theories and methods (5th ed.). New York, NY: Allyn and Bacon.

Bonanno, G. A. (2005). Resilience in the face of potential trauma. Current Directions in Psychological Science, 14(3), 135-138.

Buchanan, M., Dzelme, K., Harris, D., \& Hecker, L. (2001). Challenges of being simultaneously gay or lesbian and spiritual and/or religious: A narrative perspective. The American Journal of Family Therapy, 29, 435-449.
Cass, V. C. (1984). Homosexual identity formation: Testing a theoretical model. The Journal of Sex Research, 20(2), 143-167.

Chuang, A., Liao, W., \& Tai, W. (2005). An investigation of individual and contextual factors influencing training variables. Social Behavior and Personality, 33(2), 159-174.

Couch, M., Mulcare, H., Pitts, M., Smith, A., \& Mitchell, A. (2008). The religious affiliation of gay, lesbian, bisexual, transgender, and intersex Australians: A report from the private lives survey. People and Place, 16(1), $1-11$.

Creswell, J. W. (2007). Qualitative inquiry and research design: Choosing among five approaches ( 2 nd ed.). Thousand Oaks, CA: Sage Publications.

D'Augelli, A. R. (2006). Coming out, visibility, and creating change: Empowering lesbian, gay, and bisexual people in a rural university community. American Journal of Community Psychology, 37, 203-210. doi:10.1007/s10464-006-9043-6

Deutsch, M., Coleman, P. T., \& Marcus, E. C. (Eds.). (2006). The handbook of conflict resolution: Theory and practice (2nd ed.). San Francisco, CA: Jossey-Bass.

Donnelly, S. (2001). Building a new moral, religious, or spiritual identity: Perspective transformation in lesbian women (Unpublished doctoral dissertation). Texas A \& M University, College Station, TX.

Ezzy, D. (2002). Qualitative analysis: Practice and innovation. London, England: Routledge.

Facente, A. (2006). Humor in health care: Irreverent or invaluable? Nursing, 36(4), 64hn6-64hn7.

Fowler, J. W. (1981). Stages of faith: The psychology of human development and the quest for meaning. San Francisco, CA: Harper \& Row.

Glaser, B. G. (2007). Doing formal theory. In A. Bryant \& K. Charmaz (Eds.), The Sage handbook of grounded theory (pp. 97-113). Thousand Oaks, CA: Sage Publications.

Green, C. W., \& Hoffman, C. L. (1989). Stages of faith and perceptions of similar and dissimilar others. Review of Religious Research, 30(3), 246-254.

Laursen, E. K. (2003). Frontiers in strength-based treatment. Reclaiming Children and Youth, 12(1), 12-17.

Lease, S. H., Horne, S. G., \& Noffsinger-Frazier, N. (2005). Affirming faith experiences and psychological health for Caucasian lesbian, gay, and bisexual individuals. Journal of Counseling Psychology, 52(3), 378-388. doi:10.1037/0022-0167.52.3.378

Lease, S. H., \& Shulman, J. S. (2003). A preliminary investigation of the role of religion for family members of lesbian, gay male, or bisexual male and female individuals. Counseling and Values, 47, 195-209.

Leavitt, K. P. (2002). Create a healthy you. Natural Health, 32(5), 52-57.

Levy, D. L. (2008). Gay, lesbian, and queer individuals with a Christian upbringing: Exploring the process of resolving conflict between sexual identity and religious 
beliefs. Dissertation Abstracts International, 69(08), 282A. (UMI No. AAT 3326661)

Lukenbill, W. B. (1998). Observations on the corporate culture of a gay and lesbian congregation. Journal for the Scientific Study of Religion, 37(3), 440-452.

Mahaffy, K. A. (1996). Cognitive dissonance and its resolution: A study of lesbian Christians. Journal for the Scientific Study of Religion, 35(4), 392-402.

Maxwell, J. A. (2005). Qualitative research design: An interactive approach (2nd ed.). Thousand Oaks, CA: Sage Publications.

McQueeney, K. B. (2003, August). "Just your average Christian": Rhetorics of identity and reproducing inequality in lesbian- and gay-affirming Protestant congregations. Paper presented at the meeting of the American Sociological Association, Atlanta, GA.

Merriam, S. B. (2009). Qualitative research: A guide to design and implementation. San Francisco, CA: JosseyBass.

Mezirow, J. (1997). Transformative learning: Theory to practice. New Directions for Adult \& Continuing Education, 74, 5-12.

Miller, E. D. (2003). Reconceptualizing the role of resiliency in coping and therapy. Journal of Loss and Trauma, 8(4), 239-246. doi:10.1080/ g15325020390233057

Miller, R. J., \& Boon, S. B. (2000). Trust and disclosure of sexual orientation in gay males' mother-son relationships. Journal of Homosexuality, 38(3), 41-63.

Moran, C. C., \& Hughes, L. P. (2006). Coping with stress: Social work students and humour. Social Work Education, 25(5), 501-517.

Padgett, D. K. (1998). Qualitative methods in social work research: Challenges and rewards. Thousand Oaks, CA: Sage Publications.

Rodriguez, E. M., \& Ouellette, S. C. (2000). Gay and lesbian Christians: Homosexual and religious identity integration in the members and participants of a gaypositive church. Journal for the Scientific Study of Religion, 39(3), 333-347.

Rothery, M. (2001). Ecological systems theory. In P. Lehmann \& N. Coady (Eds.), Theoretical perspectives for direct social work practice: A generalist-eclectic approach (pp. 65-82). New York, NY: Springer Publishing Company.

Saltzburg, S. (2004). Learning that an adolescent child is gay or lesbian: The parent experience. Social Work, 49(1), 109-118.

Shallenberger, D. (1996). Reclaiming the spirit: The journeys of gay men and lesbian women toward integration. Qualitative Sociology, 19(2), 195-215.

Stephenson, R. C. (2006). Promoting self-expression through art therapy. Generations, 30(1), 24-26.

Thumma, S. (1991). Negotiating a religious identity: The case of the gay Evangelical. Sociological Analysis, 52(4), 333-347.

Vermunt, J. D. (2005). Relations between student learning patterns and personal and contextual factors and aca- demic performance. Higher Education, 49(3), 205-234. doi:10.1007/s10734-004-6664-2

White, D., \& White, O. K., Jr. (2004). Queer Christian confessions: Spiritual autobiographies of gay Christians. Culture and Religion, 5(2), 203-217. doi:10.1080/143830042000225439

Winter, G. (2006). Laughter therapy. Nursing Standard, 21(14-16), 28.

Wojciechowski, M. (2007). Tickling the funny bone: The use and benefits of humor in health care. PT: Magazine of Physical Therapy, 15(12), 21-25.

Yip, A. K. T. (1998). Gay male Christians' perceptions of the Christian community in relation to their sexuality. Theology \& Sexuality, 8, 40-51.

Yip, A. K. T. (2003). Spirituality and sexuality: An exploration of the religious beliefs of nonheterosexual Christians in Great Britain. Theology \& Sexuality, 9(2), 137-154.

\section{APPENDIX}

\section{Interview Protocol}

\section{Background Questions}

- During the prescreening, you mentioned that you grew up attending the [denomination name] church. Can you discuss what messages you heard at church related to sexuality?

- Is there any particular experience you had at church related to the conflict between Christianity and sexual orientation that you would like to share?

- Growing up, what did your family believe about homosexuality?

- Growing up, what did you believe about homosexuality?

\section{Interview Questions Related to Research Question 1}

- What kind of conflict have you experienced between your religious upbringing and your sexual identity?

- When did you first notice this conflict?

- How did you feel about this conflict?

- How did this conflict impact your life?

\section{Interview Questions Related to Research Question 2}

- What kinds of things or people influenced how you've dealt with this conflict?

- How did your environment (church, family, friends, school, community, and so forth) shape your efforts to resolve this conflict?

- What personal characteristics or traits influenced how you've dealt with this conflict?

- How, if at all, was this conflict related to your decision to come out? 
Interview Questions Related to Research Question 3

- How did you cope or deal with this conflict?

- How did you move from experiencing the conflict to resolving the conflict?

\section{Interview Questions Related to Research Question 4}

- How do you make sense of your sexual identity and Christian upbringing today?
- Some people say that religiosity and spirituality are two different things. What do you think? Do you consider yourself a religious person, a spiritual person, both, or neither?

\section{Final Questions}

- Is there anything else that we haven't discussed related to your experience resolving conflict between sexual orientation and religious beliefs that you would like to mention?

- What would your advice be to someone who is experiencing this conflict today? 